๑ Laboratorium: журнал социальных исследований. 2019. 11(1):199-205

DOI: 10.25285/2078-1938-2019-11-1-199-205

\title{
Ян Левченко
}

Lida Oukaderova. The Cinema of the Soviet Thaw: Space, Materiality, Movement. Bloomington: Indiana University Press, 2017. 216 pp. ISBN 978-0-2530-2696-5.

Ян Левченко - профессор Школы культурологии факультета гуманитарных наук Ниу ВШэ (Москва). Адрес для переписки: ул. Старая Басманная, 21/4, Москва, 105066, Россия. janlevchenko@hse.ru.

Книга Лиды Укадеровой внятно и лаконично подводит итоги изучения одной устойчивой темы. На протяжении многих лет история советского кино на разных языках вскользь и без подробностей проговаривалась, что кино эпохи оттепели отличается от кино сталинской неоклассики своими пространственными характеристиками. Но дальше варьирования общих мест о пресловутом «ощущении» свободы, которое «пленяло» и «опьяняло», дело не очень двигалось. 0 пространстве оттепельного кино множество отдельных наблюдений обнаруживается в работе Евгения Марголита «Живые и мертвое...» (2012), пространство как объект освоения в очнувшейся от морока стране не раз упомянуто в широко известной книге Жозефины Уолл «Real Images: Soviet Cinema and the Thaw» (Woll 2000), яркая работа Александра Прохорова «Унаследованный дискурс...» (2007) посвящена неудавшемуся отказу от «сталинских» тропов в кино и литературе оттепели, она акцентирует внимание на перевоспитании героя, на новых качествах человека, касаясь проблематики пространства в антитезах обобществленного и семейного, коллективного и приватного и т. д. Укадерова же, вероятно, отсылая к работе Прохорова и отталкиваясь от нее, ставит проблему пространства в центр внимания и считает ее конститутивной для кинематографа так называемой «долгой оттепели» (концептуализацию этого понятия см.: Csicsery-Ronay 2004:338).

Книга невелика по объему, она состоит из пяти кейсов, связанных общей референцией, если не считать введения и заключения, также представляющих собой не столько жанровые автометатексты, сколько фрагменты оригинального исследовательского дискурса. Вопреки установившейся традиции собирать книжки исключительно из опубликованных текстов здесь этот принцип работает лишь на треть: разделы 2 и 3 увидели свет ранее в британском журнале Studies in Russian and Soviet Cinema и американском Film and History. Все остальное - конечно, монтаж аттракционов, так как от первой до последней строки в эпоху специализации, диверсификации и повышения эффективности научные книжки не пишут, но процент оригинального материала здесь действительно на редкость высок.

При этом методология исследования, напротив, отличается все реже встречающейся целостностью, наличием сквозного подхода, вдохновленного работами социолога Анри Лефевра - в первую очередь его книгой «Производство пространства» ([1974] 2015). Конечно, столь общую рамку легко провозгласить единой, поскольку Лефевр в своем неомарксистском сочинении предложил самую 
общую модель, связывающую одним метаязыковым каркасом категории природности, ментальности и социальности. По его словам, «унитарная теория», которая ищет и не находит своих оснований ввиду отсутствия «критического момента», возвращается к дробному знанию, так и не сумев свести сумму наблюдаемых фактов к гегелевским универсалиям (см.: Лефевр [1974] 2015:26-27). Задача современной социологии - разработка языка, для которого все, что есть в культуре, есть продукт производства. Пространство производится, организуется, формуется и форматируется так же, как знание и управление (в узком смысле - конкретный менеджмент, в широком - политика).

В свою очередь, легко увидеть в этом изложении эксплицитное тяготение к фуколдианской парадигме, что уже на нескольких этапах интеллектуальной моды становилось основанием для жесткой критики (предельно огрубляя, из-за того, что Мишель Фуко в своих масштабных обобщениях половину нафантазировал, поскольку-де «реальность» «сложнее»). Именно с Фуко (и сквозь всю его биографию от «Рождения клиники» (1963) до «Других пространств» (1984)) резонирует принятый ныне термин спациализация, означающий выведение материальной и символической активности людей из особенностей населяемого ими пространства. Представление, постулирующее эту зависимость, определяет и данное исследование. В советском контексте именно оттепель знаменует переход к производству пространства: доселе широко шагавший по стране советский человек сбавляет ход и обращается к дому, в котором живет, к родственному и, что важнее, дружескому кругу. Жизнь наконец-то обживается, ранее отчужденное пространство осваивается, заполняется и делается видимым («привыкнуть - это и значит освоиться», как перифразирует автор Лефевра (с. 16)). Освоение целинных земель и начавшееся немногим позже освоение космоса - не случайные совпадения, но ключевые слова, артикулирующие эпоху.

Введение остроумно начинается с разбора неигровой картины Ильи Копалина «Город большой судьбы» (1961), где визуализируется превращение карты в реальное пространство. Щедрое на метафоры свежее десятилетие демонстрирует свои приоритеты: не только отчужденная статистика, но еще и человеческое измерение, реальный город, телесные горожане, новый гуманизм. По мнению автора, «копалинский эпизод [где сквозь разрыв карты московского центра видны повозки, старые трамваи, довоенная мода] представляет собой подходящую точку входа в заявленную тему, поскольку конкретизирует с помощью самой материи фильма первичность пространства и более всего пространственного опыта для оттепельного кинопроизводства» (с. 2). При этом Укадерова отмечает, что масштабный замысел провалился и, в отличие от других картин Копалина о Москве, «Город большой судьбы» так и не отливается в последовательную историю. Между прочим, этот фильм Копалин снимал сам, тогда как «Москва» (1927) и «Разгром немецких войск под Москвой» (1942) делались в соавторстве с Михаилом Кауфманом и Леонидом Варламовым соответственно. Несмотря на символичное время появления, фильм Копалина продемонстрировал губительные последствия самоцензуры, воспитанной сталинским госзаказом. Как обличительно и, признаться, справедливо писал другой заслуженный карьерист и служилый критик Ростислав 
Юренев, к 1960 году советские неигровые фильмы приобрели «официальный, торжественный, самодовольный тон. [...] Уже не “жизнь врасплох" и не жестокая правда, как в фильме о войне, а хорошо выверенные, уравновешенные композиции, отобранные, а порой и подготовленные к съемкам прохожие, чисто прибранные и украшенные улицы» (2014:35).

Основной массив исследования состоит из четырех монографических разделов, где предлагается пристальный анализ знаковых картин поздней оттепели. Перед этой традиционной конструкцией размещается любопытный раздел о кинопанораме на ВДНХ - характерном кунштюке середины прошлого столетия, который на новом витке технологий воспроизводил эффект присутствия внутри представления, впервые опробованный шотландцем Робертом Баркером в 1789 году (подробнее: Comment [1960] 1999:23-28; Uricchio 2011). Круговая кинопанорама, почти погружающая мобильного зрителя в действие, видится автору попыткой конструирования освобожденного и самосознающего индивида, чье перемещение в пространстве произвольно, а не обусловлено чужой волей. Панорамное кино было не только в СССР, который и здесь просто старался не отстать от мировых трендов. Но именно в тоталитарном контексте опыт присутствия, или даже испытания зрителем своего соприсутствия с тем, что воплощено на экране (с. 45), санкционирует и воспитывает чувство свободы. Как явствует из синхронной критики, панорама вызывала противоречивую реакцию, что исследовательница связывает с амбивалентным отношением к фотографии, которая в сталинскую эпоху лишилась статуса безусловного доказательства и аутентичного документа (ср. удаление неугодных политических деятелей из всех медийных изображений после очередной волны террора). Тем не менее, панорама сыграла определяющую роль в деле освоения советским человеком сначала внешнего (география Страны (оветов), а позднее, в эпоху застоя, и своего внутреннего мира. В этой главе обращают на себя внимание не вполне объяснимые датировки выхода панорамных фильмов: Укадерова пишет о диапазоне с 1967 по 1987 год, не приводя ссылки на источник, хотя ресурсы, имеющие отношение к работе ныне реконструируемого панорамного кинотеатра, называют 1959-1993 годы ${ }^{1}$.

Тематика и структура последующих четырех разделов позволяет говорить об их единообразии, по крайней мере - о сквозной композиции. Речь идет о нескольких способах пространственной эмансипации персонажей и вещей в кинематографе оттепели. Не только человек обучается перемещаться по разным, никем, кроме него/нее, не определенным траекториям, но и предметы (например, дома, целые улицы, элементы жилища и потребительские фетиши от грампластинок до сервизов) вступают в новые отношения с человеком и образуют новые конфигурации. Так, в главе об эпохальной картине Георгия Данелии «Я шагаю по Москве» (1963) речь, по мнению автора, идет о пересобирании города - очень позитивного и приподнятого, но принципиально отличного от парадной стати предыдущего поколения фильмов. Москва Григория Александрова - место риту-

1 См.: официальный сайт Выставки достижений народного хозяйства (http://vdnh.ru/ map/4255/), Кинотеатр «Круговая кинопанорама» (http://krugorama.narod.ru). 
альное, подчиняющее движение персонажей логике концентрических кругов, сужающихся у Кремля, ВДНХ и высоток, вставших в преддверии смерти Сталина башнями невидимой твердыни. В картине Данелии, напротив, Москва состоит из разнонаправленного движения, мокрых и сохнущих на ветру фактур, не столько самой архитектуры, сколько ее теней и бликов. Когда же архитектура появляется в кадре, она принципиально очеловечена - как, например, в жилых московских переулках или в инициальном эпизоде с отражением девушки в зеркальной стене аэровокзала, цитирующем «Время развлечений» Жака Тати (1967).

Данелия соответствует первому элементу хрестоматийной базеновской оппозиции между «реальностью драматического пространства» и «монтажной манипуляцией образами»; это кино, где режиссер имеет дело с театром реальности, а не создает выхолощенную конструкцию на монтажном столе (с. 100). Совсем не так обстоит дело в предельно управляемом, подчиненном сильнейшей визуальной концепции мире Михаила Калатозова и Сергея Урусевского. Его Укадерова анализирует в главе, посвященной двум картинам тандема - «Неотправленное письмо» (1959) и «Я - Куба» (1964). Примечательно, что обе работы не были приняты критикой и, тем более, зрителями с тем же восхищением, что сопровождало появление этапного для советского кинематографа фильма «Летят журавли» (1957). Их ругали за непонятность и утомительную многозначительность, за отсутствие действия и одновременную идеологизированность на грани здравого смысла. Примечательно, что одна из кубинских рецензий на вторую из упомянутых картин называлась «Я не Куба» (с. 81). Автор, однако, считает, что по преимуществу визуальный эксперимент с материалом, продолжающий работу, начатую в «Журавлях», вовсе не тормозит развитие повествования, но лишь усложняет его, делая сам процесс восприятия и освоения пространства и его пробную сборку после распада старых связей сталинской эпохи первичными для понимания сюжета (с. 51). В самом деле, история заблудившихся искателей алмазов, прекрасно отражающая характерный номадизм нового «оттепельного» человека, и разорванная, состоящая из отдельных новелл экскурсия по Острову Свободы, снятая на грани изысканного мокьюментари, в равной степени обнаруживают зависимость от движения камеры, которая передает движение времени и человеческого чувства. Собственно, именно камера Урусевского утвердилась в этих картинах как важнейший субъект действия, невиданный со времен «Человека с киноаппаратом» Дзиги Вертова (1929). Комментируя дерзкие жесты Урусевского, автор пишет, что его тактика невольно разрабатывала на практике почти синхронную мысль Кристиана Метца о том, что «в кино впечатление реальности является также реальностью впечатления, реального присутствия некоторого наблюдаемого, но мнимого движения» (с. 74-75). Как следствие, событийный уровень картин - не более чем следование за камерой. Иллюстрацией этой власти служит снятая без стыков вводная сцена в гаванском отеле эпохи Президента Фульхенсио Батисты. Да и похороны юного революционера, производящие мистическое впечатление, так как кажутся снятыми с дрона, не существовавшего в те времена, можно счесть достаточным доказательством сказанного. Укадерова находит для этого эффекта не менее эффектное название - «миметические пассажи». Добавить нечего. 
Тандем Калатозова и Урусевского, пожалуй, ярче других мастеров оттепели дал понять, что у советского авангарда 1920-х годов появились преемники. Помимо Вертова, мифотворцы кубинской революции актуализировали, само собой, Сергея Эйзенштейна. Одна из самых теоретически заряженных реминисценций состоит, как кажется, в вопиющем контрасте между утонченным визуальным решением и грубейшим пропагандистским посланием. Правда, в отличие от горячего пореволюционного авангарда, прохладный послевоенный модернизм с готовностью обнажает фальшь революционного пафоса - в 1960-е сюжет 1920-х не работает. Бедняки заслужили свою участь, а борцы за свободу гибнут, как форменные идиоты, - мысль, что авторы фильма намеренно выставляли их в таком свете, крепнет от новеллы к новелле, хотя это, безусловно, ретроспективная иллюзия.

Одним из громких «тревожных звонков», разрушающих внешнее единство и общее стремление эпохи к освобождению, становится в книге Укадеровой амбивалентная, значительно опередившая свое время картина Ларисы Шепитько «Крылья» (1966). Это - поздняя оттепель, чьи эффектные приемы еще работают в кино, но смысл их дрейфует в сторону большей сложности. Будто еще вчера позитивные горожане вдруг сворачивают с умытых улиц в подворотни, где подпирают стенку герои «Трех дней Виктора Чернышева» (Марк Осепьян, 1968), или набиваются в квартиры, появляющиеся в «Заставе Ильича», а в «Июльском дожде» (Марлен Хуциев, 1964 и 1966) уже смертельно надоевшие завсегдатаям. Магистральная тема «Крыльев» - ревизия гендерных ролей, которую консервативный зритель сочтет, скорее, вынужденной («если бы не война...»), а прогрессивный, напротив - последовательной и симптоматичной. Режиссер-женщина, снимающая историю о летчике-женщине, написанную сценаристом-женщиной - не самый рядовой случай для советского кино, которое в только что завершившейся на тот момент первой половине столетия не имело понятия о феминизме, несмотря на устойчивый процент режиссеров-женщин от Ольги Преображенской и Эсфири Шуб до Надежды Кошеверовой и Суламифь Цыбульник. Оттепельные опыты Татьяны Лиозновой, в первую очередь «Евдокия» (1961), были важны в первопроходческом смысле, но особой радикальностью эта экранизация смелой для своего времени повести Веры Пановой похвастаться не могла - дискурсивная рамка патриархальных привычек лишь слегка колебалась, допуская, по крайней мере, мысль о добрачной любви. Должна была прийти Лариса Шепитько, чтобы директриса профтехучилища, в прошлом бесстрашная летчица, пела в подпитии мелодию Штрауса и танцевала лесбийский вальс с буфетчицей под изумленными взглядами мужчин в окне.

Пространство в «Крыльях» - уже не дружественный мир, которому нужно верить - и все будет хорошо. Здесь главенствует отчуждение, и руинам в душе, буквально рухнувшим надеждам (героиню зовут Надежда) соответствуют перегруженные интерьеры, противопоставленные небесному простору. Главу об этом фильме Укадерова эффектно называет «Прогулка через руины» и даже использует метафору фланирования, чтобы подчеркнуть параллель пеших маршрутов героини с полетами в ее памяти (с. 126-134). В забытьи Надежда блу- 
ждает по городу, практически не видя его - камера крайне скупо показывает Севастополь, в котором проходили съемки фильма. Это не совсем фланирование, так как столь значимые для фланера урбанистические ландшафты не играют здесь никакой роли - героиня потеряла на войне не только любовь, но и самое себя, и ей не суждено обрести себя в этих перемещениях. А разрушенная войной личность в версии Шепитько резонирует с современностью, ее несбывшимися надеждами.

Финальным аккордом «долгой счастливой жизни», из которой так ничего и не вышло, в логике книги становится картина Киры Муратовой «Короткие встречи» (1967) - послесловие к оттепели, оно же инициальное кино раннего застоя. Сама Муратова -художница, взращенная оттепелью, но ее вхождение в профессию совпадает с крушением утопий, питавших энтузиазм страны после смерти Сталина, и ее судьба связана с необходимостью диагностировать постепенно деградирующий мир советского обывателя. Иронично, что в своем полнометражном дебюте она сама сыграла роль партийной функционерши, увлеченной вышедшим в тираж геологом и стремящейся удержать его дома материальными эквивалентами достатка, уюта, сытости. Муратова дискредитирует «женский мир» в своей картине, зная его изнутри. За отсутствием развитого метаязыка гендерных отношений она не просчитывает обвинения в мизогинии - о них пока говорить не приходится. В фильме, по мнению Укадеровой, постулировано различие между фрагментарным миром «женских» вещей, лишенных значений и сводящихся лишь к собственной функции, и объемным, целостным миром трансцендентной, «подлинной» жизни, который закрепляется за надуманной сконструированной маскулинностью (с. 177). Симптом завершения оттепели - превращение сформированного предметами и мыслями «картезианского» пространства в служебную «ньютоновскую» пустоту, которую люди снова в упор не хотят замечать, занимаясь собой и устраивая, как им кажется, свои «важные» житейские дела.

По наблюдению Укадеровой, интересным случаем переворачивания ролей с сохранением базового сюжета оказывается по отношению к «Коротким встречам» фильм Андрея Звягинцева «Елена» (2011), - обоснованию этой параллели посвящено заключение книги. Если неформальный характер введения с анализом неигрового фильма о Москве способствовал созданию интриги, то лаконичное заключение, в отчетливо конъюнктурном ключе привлекающее к рассмотрению более или менее известного в США (в отличие от остальных имен) современного режиссера, эту интригу, к сожалению, не разрешает. Ключевой тезис об «инаковости» (otherness) пространства, создаваемого в «Елене» и якобы вступающего в полемический диалог с фильмами оттепели, обоснован слишком скупыми и общими характеристиками. Остается гадать, зачем автору вдруг понадобился Звягинцев, если не сводить все к уже отмеченным особенностям его творческой репутации. Как следствие, в высшей степени убедительная, изящная (несколько перегруженная наукообразностью) и безупречно выстроенная книга неожиданно схлопывается в поспешном сравнении с «актуальной» повесткой и повисает на недоуменном многоточии... 


\section{СПИСОК ЛИТЕРАТУРЫ}

Лефевр, Анри. [1974] 2015. Производство пространства. М.: Strelka Press.

Марголит, Евгений. 2012. Живые и мертвое. Заметки к истории советского кино 1920-1960-х 22. СПб.: Мастерская «Сеанс».

Прохоров, Александр. 2007. Унаследованный дискурс: парадигмы сталинской культуры в литературе и кинематографе «оттепели». Т. 66. СПб.: Академический проект.

Юренев, Ростислав. 2014. «Три Москвы Ильи Копалина». С. 33-34 в Мастерская И.П. Копалина. Страницы истории ВГИКа: Учебное пособие. С иллюстрациями, сост. Виктор Лисакович. М.: ВГИК.

Comment, Bernard. [1960] 1999. The Panorama. London: Reaktion.

Csicsery-Ronay, Istvan, Jr. 2004. "Soviet Science Fiction: The Thaw and After." Science Fiction Studies 31(3):337-344.

Uricchio, William. 2011. “A 'Proper' Point of View: The Panorama and Some of Its Early Media Iterations." Early Popular Visual Culture 9(3):225-238.

Woll, Josephine. 2000. Real Images: Soviet Cinema and the Thaw. London: I. B. Tauris. 